\title{
The success of the cyanobacterium Cylindrospermopsis raciborskii in freshwaters is enhanced by the combined effects of light intensity and temperature
}

\author{
Sylvia BONILLA,,${ }^{1,2}$ Mauricio GONZÁLEZ-PIANA, ${ }^{1,2}$ Maria C.S. SOARES, ${ }^{3}$ Vera L.M. HUSZAR, ${ }^{4}$ Vanessa BECKER,, 5 \\ Andrea SOMMA,${ }^{1,2}$ Marcelo M. MARINHO,${ }^{6}$ Mikołaj KOKOCIŃSKI, ${ }^{7}$ Martin DOKULIL,${ }^{8}$ Dermot ANTONIADES, ${ }^{1,9}$ \\ Luis AUBRIOT ${ }^{1,2}$
}

\begin{abstract}
${ }^{1}$ Grupo de Ecología y Fisiología de Fitoplancton, Universidad de la República; ${ }^{2}$ Sección Limnología, Facultad de Ciencias, Universidad de la República, Iguá 4255, 11400 Montevideo, Uruguay; ${ }^{3}$ Departamento de Engenharia Sanitária e Ambiental, Universidade Federal de Juiz de Fora, Juiz de Fora, Brazil; ${ }^{4}$ Museu Nacional, Universidade Federal do Rio de Janeiro, Rio de Janeiro, Brazil; ${ }^{5}$ Centro de Tecnologia, Departamento de Engenharia Civil, Universidade Federal do Rio Grande do Norte - UFRN, Natal, Brazil; ' Departamento de Biologia Vegetal, Laboratório de Ecologia e Fisiologia do Fitoplâncton, Universidade do Estado do Rio de Janeiro, Rio de Janeiro, Brazil; ' Department of Hydrobiology, Adam Mickiewicz University, Umultowska 89, 61-614 Poznań, Poland; ${ }^{8}$ Institute of Limnology, Austrian Academy of Sciences, Mondsee Strasse 9, A-5310 Mondsee, Austria; ${ }^{9}$ Département de Géographie and Centre d'études nordiques, Université Laval, Quebéc, G1V 0A6, Canada

*Corresponding author: sylvia.e.bonilla@gmail.com, sbon@fcien.edu.uy
\end{abstract}

\section{ABSTRACT}

Toxic cyanobacterial blooms in freshwaters are thought to be a consequence of the combined effects of anthropogenic eutrophication and climate change. It is expected that climate change will affect water mixing regimes that alter the water transparency and ultimately the light environment for phytoplankton. Blooms of the potentially toxic cyanobacterium Cylindrospermopsis raciborskii are expanding from tropical towards temperate regions. Several hypotheses have been proposed to explain this expansion, including an increase in water temperature due to climate change and the high phenotypic plasticity of the species that allows it to exploit different light environments. We performed an analysis based on eight lakes in tropical, subtropical and temperate regions to examine the distribution and abundance of $\mathrm{C}$. raciborskii in relation to water temperature and transparency. We then conducted a series of short-term factorial experiments that combined three temperatures and two light intensity levels using $\mathrm{C}$. raciborskii cultures alone and in interaction with another cyanobacterium to identify its growth capacity. Our results from the field, in contrast to predictions, showed no differences in dominance $(>40 \%$ to the total biovolume) of $\mathrm{C}$. raciborskii between climate regions. C. raciborskii was able to dominate the phytoplankton in a wide range of light environments (euphotic zone $=1.5$ to $5 \mathrm{~m}$, euphotic zone/mixing zone ratio $<0.5$ to $>1.5$ ). Moreover, C. raciborskii was capable of dominating the phytoplankton at low temperatures $\left(<15^{\circ} \mathrm{C}\right)$. Our experimental results showed that $\mathrm{C}$. raciborskii growing in interaction was enhanced by the increase of the temperature and light intensity. C. raciborskii growth in high light intensities and at a wide range of temperatures, suggests that any advantage that this species may derive from climate change that favors its dominance in the phytoplankton is likely due to changes in the light environment rather than changes in temperature. Predictive models that consider only temperature as a drive factor can therefore fail in predicting the expansion of this potentially toxic cyanobacterium.

Key words: Harmful algal blooms (HABs); management; climate change; phenotypic plasticity; water transparency.

Received: April 2016. Accepted: June 2016.

\section{INTRODUCTION}

Predicted increases in temperature due to climate change will enhance the risk of potentially toxic cyanobacterial blooms in freshwaters (Paerl and Paul, 2012), threatening drinking water, recreation activities and other water uses. Furthermore, changes in mixing regimes and water column transparency that will accompany increased temperatures are also critical factors that will influence future phytoplankton composition and growth (Doney, 2006; Karlsson et al., 2009). A recent major concern is the rise of toxic blooms of filamentous cyanobacteria belonging to the order Nostocales, in particular Cylindrospermopsis raciborskii (Sukenik et al., 2012). This species was originally described as a tropical cyanobacterium (reviewed in Padisák, 1997) and has been cited as an invasive species (sensu Litchman, 2010) due to its apparent expansion from the tropics to temperate regions, where it now can form dense blooms (Padisák, 1997; Sinha et al., 2012), potentially harmful due to the production of potent toxins (saxitoxin or cylindrospermopsin) (Piccini et al., 2011). Hypotheses that explain the expansion of $C$. raciborskii include an increase in water temperatures due to climate change (Wiedner et al., 2007), phenotypic plasticity that allows the species to exploit a wide range of light conditions due to pigment acclimation (Bonilla et al., 2012; Mehnert et al., 2012) and the capacity to grow under very low phosphate concentrations (Isvánovics et al., 2000; Amaral et al., 2014). 
Studies of $C$. raciborskii ecology indicate that the species can dominate the phytoplankton community in a wide range of aquatic environments, deep to shallow, and mesotrophic to eutrophic lakes (Everson et al., 2011; Sinha et al., 2012; Sukenik et al., 2012; Soares et al., 2013). In these environments other cyanobacteria may also commonly alternate in dominance with $C$. raciborskii, including the colonial Microcystis aeruginosa (Marinho and Huszar, 2002; Soares et al., 2009) and the filamentous Planktothrix agardhii and Aphanizomenon sp. (Kokociński et al., 2010; Bonilla et al., 2012). Planktothrix agardhii is a filamentous cyanobacterium that can grow forming resilient, dense blooms in shallow eutrophic ecosystems at different latitudes (Scheffer et al., 1997; Bonilla et al., 2012). P. agardhii and C. raciborskii can also co-occur in the same water bodies (Kokociński et al., 2010; Bonilla et al., 2012) and, therefore, they are excellent model species for use in tests of $C$. raciborskii's growth capacity. This capacity may be evaluated using experimental studies that assess its response to changing environmental factors in combination with other similar species.

Increased temperatures are often accepted as the main physical factor that regulates the distribution of Cylindrospermopsis raciborskii worldwide (Padisák, 1997; Sukenik et al., 2012). However, different temperature values $\left(13^{\circ} \mathrm{C}\right.$ and $20^{\circ} \mathrm{C}$ ) for akinete germination have been reported in the literature (Padisák, 1997; Rücker et al., 2009), while other studies showed high $C$. raciborskii biomass in freshwaters at lower temperatures $\left(11\right.$ to $19^{\circ} \mathrm{C}$ ) (Everson et al., 2011; Bonilla et al., 2012) and experimental evidence has shown that $C$. raciborskii growth rates have high variability at differing temperatures $\left(15\right.$ to $40^{\circ} \mathrm{C}$ ) (Briand et al., 2004; Soares et al., 2013). Overall, the available evidence indicates that $C$. raciborskii can succeed across a wide range of water temperatures and does not support the hypothesis that temperature is a limiting factor for its success.

Since the original classification of $C$. raciborskii as a shade-tolerant species (Padisák and Reynolds, 1998) with low saturation light intensities for growth $\left(\mathrm{I}_{\mathrm{k}}<26 \mu \mathrm{mol}\right.$ photon $\mathrm{m}^{-2} \mathrm{~s}^{-1}$ ) (Briand et al., 2004), new evidence has shown that this species has a high phenotypic plasticity that may explain its good performance at high light intensities (Saker and Eaglesham, 1999; Piccini et al., 2011; Bonilla et al., 2012; Pierangelini et al., 2014). Thus, light intensity itself may be not sufficient to explain the expansion of $C$. raciborskil, since it was reported to tolerate both low and high light intensities in temperate (Dokulil and Teubner, 2000; Wiedner et al., 2007) and tropical regions (Soares et al., 2009; Gomes et al., 2013).

The roles of water transparency and light intensity in generating favorable conditions for the colonization of $C$. raciborskii are therefore not clear. The general problem of $C$. raciborskii expansion has not been thoroughly ad- dressed despite the vast literature about this species (for reviews, see Padisák, 1997, Komárek and Komárková, 2003, and Sinha et al., 2012). Most of the available ecological and physiological studies analyze the response of C. raciborskii to single variables (i.e., temperature or light), while few attempts have been made to explore the combined effects of these two factors in the species' performance (Bittencourt-Oliveira et al., 2011; Bonilla et al., 2012; Sinha et al., 2012; Kehoe et al., 2015), which could improve the interpretation of its distribution.

Based on experiments, in a previous study we found that the combination of warm temperature $\left(25^{\circ} \mathrm{C}\right)$ with high light intensity $\left(135 \mu \mathrm{mol}\right.$ photon $\left.\mathrm{m}^{-2} \mathrm{~s}^{-1}\right)$ resulted in a significant increase in $C$. raciborskii growth rates (Bonilla et al., 2012). These results provide an excellent starting point to explore the growth capacity of $C$. raciborskii in mixed cultures and to analyze its distribution in ecosystems with different water transparency and temperature.

In this study we work with a simple but realistic scenario. We designed short-term interaction experiments in which C. raciborskii was added as an inoculum to another cyanobacteria culture (Planktothrix agardhii). This species was selected for the interaction experiments because it co-occurs in nature with $C$. raciborskii (Kokociński et al., 2010) and the two taxa have overlapping environmental preferences (i.e., turbidity and mixing tolerance, growth in a wide range of temperatures) (Briand et al., 2002; Kokociński et al., 2010; Bonilla et al., 2012). The interaction experiments allow us to test the combined influence of temperature and light intensity on the growth capacity of $C$. raciborskii. We also integrate field and experimental data to study the distribution and growth of $C$. raciborskii and its relationship to water column transparency (i.e., the euphotic zone), light intensity and temperature changes. We analyzed a set of temperate, subtropical and tropical lakes where C. raciborskii occurred to determine the implications of these abiotic factors for the dominance of the species.

\section{METHODS}

\section{Growth experiments under a combination of temperature and light levels}

Short-term experiments were performed to compare the growth and morphological changes of $C$. raciborskii under different conditions of light and temperature in monocultures as well as mixed cultures with $P$. agardhii. Two Uruguayan isolates from eutrophic lakes were used: $P$. agardhii (MVCC11) (from Lago Rodó) and C. raciborskii (MVCC14) (from Laguna Blanca) and maintained in BG11 full medium as described in Piccini et al. (2011).

To determine the effect of light intensity and temperature on $C$. raciborskii growth rates, triplicate growth curves were obtained in 96 hour experiments under two 
different light levels (60 and $135 \mu \mathrm{mol}$ photons $\mathrm{m}^{-2} \mathrm{~s}^{-1}$ ) and three temperature levels (low, medium and high: 15, 20 and $25^{\circ} \mathrm{C}$, respectively). The light intensities were defined based on previous works (Bonilla et al., 2012 and reviewed in Burford et al., 2016) and summarized as low (60 $\mu$ mol photons $\mathrm{m}^{-2} \mathrm{~s}^{-1}$, below saturation intensity for growth) and high (135 $\mu \mathrm{mol}$ photons $\mathrm{m}^{-2} \mathrm{~s}^{-1}$, saturation) for comparison. The two factors were combined in a factorial design: low $\left(\mathrm{L}_{\mathrm{L}}\right)$ and high $\left(\mathrm{H}_{\mathrm{L}}\right)$ light at low, medium and high temperature $\left(\mathrm{L}_{\mathrm{T}}, \mathrm{M}_{\mathrm{T}}\right.$ and $\mathrm{H}_{\mathrm{T}}$, respectively) to obtain six experimental conditions $\left(\mathrm{L}_{\mathrm{L}} \mathrm{L}_{\mathrm{T}}, \mathrm{L}_{\mathrm{L}} \mathrm{M}_{\mathrm{T}}\right.$ and $\mathrm{L}_{\mathrm{L}} \mathrm{H}_{\mathrm{T}}$, and $\mathrm{H}_{\mathrm{L}} \mathrm{L}_{\mathrm{T}}, \mathrm{H}_{\mathrm{L}} \mathrm{M}_{\mathrm{T}}$ and $\mathrm{H}_{\mathrm{L}} \mathrm{H}_{\mathrm{T}}$ ). Before beginning the experiments, cultures were acclimated to each light intensity and temperature level for 10 to 15 days as described in Bonilla et al. (2012). Since we wanted to evaluate the growth of C. raciborskii while in interaction with another cyanobacterium, mixed cultures were designed. Cultures in exponential growth phase were selected for the experiment. Interaction experiments were performed by mixing the two species so that the $C$. raciborskii inocula represented $20 \%$ to $25 \%$ of the initial total biovolume, calibrated both by optical density (absorbance at $750 \mathrm{~nm}$ ) and by counting under the microscope with a Sedgwick-Rafter chamber ( $1 \mathrm{~mL}$ volume). Before mixing, the density of both cultures was evaluated separately. Then, in $100 \mathrm{ml}$ borosilicate culture bottles with fresh BG-11 medium, inocula of each culture, growing in exponential phase, were added to reach the proportion mentioned above and final culture volume was adjusted to $80 \mathrm{~mL}$. The procedure was repeated three times to obtain three replicates. Bottles were kept with a bubbling system of sterile air and a light:darkness photoperiod of 16:8 h. Growth was evaluated by counting the filaments in $1 \mathrm{~mL}$ Sedgwick-Rafter chambers under an Olympus BX40 optical microscope at 200x magnification for each condition and time (initial, 48 and 96 hours). Sixty filaments of each replicate and each species (C. raciborskii and $P$. agardhii) were then measured (length and width) under a microscope at 1000x magnification to calculate the maximum linear dimension (MLD), volume, and surface/volume ratio. The individual volume was used to calculate the biovolume of the population $\left(\mathrm{mm}^{3} \mathrm{~L}^{-1}\right)$. To follow the mono- and mixed cultures absorbance at $750 \mathrm{~nm}$ was measured every day and was used as a proxy of bulk biomass. Light intensity within the bottles was derived from the light extinction coefficient calculated from the absorbance at $440 \mathrm{~nm}$ according to Kenesi et al. (2009) and Kirk (1994). The growth rate $\left(\mu, \mathrm{d}^{-1}\right)$ of each isolate was obtained from the slope of the linear function for each replicate between transformed biovolume ( $(n)$ and time. Data for growth curves of the two species in monoculture were obtained from Bonilla et al. (2012), who performed experiments in parallel under the same conditions. The growth capacity $(g c)$ of C. raciborskii was measured as the rate of its population change in mixed cultures, and was calculated for each experiment and each replicate based on Sperfeld et al. (2010) using the formula:

$$
g c=\log _{2}\left(\frac{\mathrm{BCr} f}{\mathrm{BCr} i}\right)
$$

where $\mathrm{BCr} f$ and $\mathrm{BCr} i$ are the species biovolume at 96 (final) and 0 (initial) hours, respectively. When $g c=0$, the species biovolume is unchanged, $g c>0$ indicates an increase in biovolume while $g c<0$ indicates a negative growing effect in the mixed cultures.

\section{Field data}

We constructed a matrix of 219 data from eight lakes distributed in temperate, subtropical and tropical regions (Tab. 1). Samples were collected following an annual cycle (except for Bnińskie and Bytyńskie lakes, Poland, sampled from July to October) for different years: lakes Funil (2002), Juturnaíba (1996, 1997), Cruzeta $(2010,2011)$ and Tabocas reservoirs, Brazil (1997, 1998); Javier Lake, Uruguay (2012, 2013); Bnińskie (2004, 2005) and Bytyńskie $(2004,2005)$ lakes, Poland; and Alte Donau Lake (1993, 1994), Austria. All data were obtained following standard limnological methods with comparable analysis routines. Lake and species data were obtained from published ( $\mathrm{n}=105)$ (Dokulil and Mayer, 1996; Marinho and Huszar, 2002; Soares et al., 2009; Kokociński et al., 2010; Bonilla et al., 2012; Dokulil, 2015) and unpublished $(\mathrm{n}=114)$ data (kindly provided by F. Bressan and L. de Castro Medeiros). The eight lakes in our database varied in size and depth and had mesotrophic to hypereutrophic conditions (Tab. 1). The following environmental variables were used in our analyses: lake area (area, ha), water temperature $\left(\mathrm{T},{ }^{\circ} \mathrm{C}\right)$, maximum depth $\left(\mathrm{z}_{\max }, \mathrm{m}\right)$, euphotic zone $\left(z_{e u}, m\right)$ and the ratio of the euphotic zone to the mixed zone $\left(\mathrm{z}_{\mathrm{eu}} / \mathrm{z}_{\mathrm{mix}}\right)$. These two last variables $\left(\mathrm{z}_{\mathrm{eu}}\right.$ and $\left.\mathrm{z}_{\mathrm{eu}} / \mathrm{z}_{\mathrm{mix}}\right)$ were chosen as proxies to describe the light climate because they are both derived from apparent optical water properties; they are easy to measure, extensively used in the literature and indicate, in relative terms, the light conditions for phytoplankton (Jensen et al., 1994; Reynolds, 2006). A ratio of $z_{\mathrm{eu}} / z_{\text {mix }} \geq 1$ indicates high light availability for phytoplankton cells, while values $<0.2$ indicate strong light limitation (Wofsy, 1983; Reynolds, 2006).

Phytoplankton sampling followed routine protocols as detailed in Bonilla et al. (2012) and Kokociński et al. (2010). Phytoplankton samples were obtained in the euphotic zone and fixed with Lugol's solution. In six lakes (Alte Donau, Javier, Funil, Tabocas, Juturnaiba and Cruzeta) phytoplankton were counted in random fields, using sedimentation chambers and the inverted microscope technique (Utermöhl, 1958), until 100 individuals of the most abundant instead of frequent species was reached, while in Bnińskie and Bytyńskie lakes samples 
were counted on an upright microscope in 160 fields of a Fuchs-Rosenthal chamber (Kokociński et al., 2010). Individual volume was calculated for each taxon according to the geometric models suggested by Hillebrand et al. (1999) and biovolume was expressed as $\mathrm{mm}^{3} \mathrm{~L}^{-1}$. The absolute biovolume of $C$. raciborskii and its relative contribution $(\%$ C. raciborskii) to total biovolume $(\mathrm{BV})$ were analyzed.

\section{Data analysis}

Biological data did not fulfill the assumptions of normality and homogeneity of variance even after simple transformations, and thus a combination of statistical approaches based on non-normal distributions were used to explore relationships between variables. To examine the combined effects of temperature and light we tested the correlation (or absence thereof) between water temperature and $\mathrm{z}_{\mathrm{eu}}$ and $\mathrm{z}_{\mathrm{eu}} / \mathrm{z}_{\mathrm{mix}}$. To explore trends between variables, the non-parametric Spearman rank order correlation was run between the relative contribution of $C$. raciborskii to total biovolume (hereafter $\%$ C. raciborskii), the coefficient of variation $(\mathrm{CV})$ of the $\%$ C. raciborskii, temperature, $\mathrm{z}_{\mathrm{eu}}$ and $\mathrm{z}_{\mathrm{eu}} / \mathrm{z}_{\text {mix }}$. To test for differences in $\% C$. raciborskii between lakes and climates (tropical, temperate and subtropical) a Kruskal-Wallis (K-W) one-way analysis of variance on ranks was performed. Then, when significant differences were found, an all pairwise multiple comparison procedure (Dunn's Method) was applied. Interpolation of raw data using inverse distance weighting was performed to construct a response 3D surface and contour plot of the $\%$ C. raciborskii ( $>10 \%$ of total biovolume) to water temperature and the $\mathrm{z}_{\mathrm{eu}} / \mathrm{z}_{\text {mix }}$ ratio from field information illustrating the relationships between the three numeric variables using the program Grapher 9.0.

Cylindrospermopsis raciborskii responses to temperature, $\mathrm{z}_{\mathrm{eu}} / \mathrm{z}_{\mathrm{mix}}$ and latitude were explored by fitting regression models using a Generalized Linear Modeling (GLM) approach appropriate for non-normal error distributions (i.e., binomial) (Birks, 2012). Prior to GLM analysis, the dataset was categorized according to $C$. raciborskii contribution to total biovolume into two classes $(0,1)$. Two datasets were constructed; in the first, class 1 was assigned to samples in which $C$. raciborskii represented $\geq 10 \%$ of total biovolume (non-rare species), and class 0 was assigned to samples $<10 \%$ of total biovolume. In the second dataset, class 1 included samples $\geq 40 \%$ (dominant species), and class 0 included all data below $(<40 \%)$. Environmental variables (water temperature, $\mathrm{z}_{\mathrm{eu}} / \mathrm{z}_{\text {mix }}$ and latitude in decimal format) were standardized and 'lake' was included as a factor. We created models with binomial error distribution and logit link function that are appropriate for 0-1 data (Birks, 2012) and the model with the best fit was selected based on Akaike's information criterion (AIC; deleting a term whenever $\triangle \mathrm{AIC}>2$ ). The factor 'lake' was not significant in the first models and consequently was removed. Latitude was used as a proxy of climate and differences between lakes (given that all lakes were distinguished by their differing latitudes). To check the goodness of fit of the models we tested for unusual observations with the leverage index (Birks, 2012); unusual data were removed and the model was run again. We explored the residual distribution by plotting the deviance residuals against their theoretical quantiles and determining the reference bands to verify the plots were a straight line, following Augustin et al. (2012). We selected this method as the best option for a residual analysis of a binomial model (Faraway, 2006; Augustin et al., 2012), that usually does not follow a normal error distribution. The variance explained by the models was summarized with $\mathrm{D}^{2}$ [(deviance of the null model-residual deviance)/ deviance of the null model*100] (Guisan and Zimmermann, 2000).

A second generalized linear model was employed to detect significant differences in C. raciborskii growth rates between the different treatments of mono- and mixed cultures (categorical factors: temperature, light intensity, culture condition). Data distribution was examined before the analysis for normality and equal variance (ShapiroWilk and Levene tests, respectively). Data distribution, although with deviation from normality, had equal variance, so the analysis was performed using normal distribution (best fit) and an identity link function. Two-way analysis of variance was performed to test significant differences and interaction between the factors temperature and light intensity on the growth capacity $(g c)$ of $C$. raciborskii. All statistical analyses were run with the software Statistica 6.0 and R 3.0.3.6 (function lmer enfolded in the package $(m e 4)$.

\section{RESULTS}

\section{Growth models of $\boldsymbol{C}$. raciborskii in mixed cultures}

The culture trichome density variation and the growth rates in short-term experiments showed that light intensity and temperature affected the growth of C. raciborskii and that there was interaction between the two factors (Figs. 1 and 2; Tab. 1). However, P. agardhii did not change significantly under different light intensities, and temperature was the only factor that explained changes in trichome density and growth rate (Figs. 1 and 2; Tab. 1). C. raciborskii grew significantly faster at $\mathrm{H}_{\mathrm{L}} \mathrm{H}_{\mathrm{T}}$ and second fastest at $\mathrm{L}_{\mathrm{L}} \mathrm{H}_{\mathrm{T}}$ (Fig. 2). C. raciborskii growth was enhanced by higher light intensities and temperatures, as well as by the combined effect of high values of both variables (Tab. 1, Fig. 2). C. raciborskii growth rates $\left(\mathrm{d}^{-1}\right) \mathrm{did}$ not differ significantly between monocultures and mixed cultures, and thus no interaction (positive or negative) was detected in the presence of $P$. agardhii (Fig. 2, Tab. 1). In 
contrast, $P$. agardhii growth responded to increases in temperature, with no differences between mono- and mixed cultures (Fig. 2, Tab. 1). In one treatment, $\mathrm{H}_{\mathrm{L}} \mathrm{H}_{\mathrm{T}}, P$. agardhii growth in mixed cultures was higher than $\mathrm{L}_{\mathrm{L}} \mathrm{H}_{\mathrm{T}}$, suggesting that it was favored by the presence of $C$. raciborskii (Fig. 2).

The growth capacity of $C$. raciborskii in mixed cultures was always positive $(g c>0)$, indicating that the species was capable of growth over a wide range of temperatures and in both high and low light intensities (Fig. 3). The expansion of $C$. raciborskii inoculum into $P$. agardhii cultures was significantly promoted by increases in temperature (ANOVA, $\mathrm{F}=56.09, \mathrm{P}<0.001$ ) or light intensity (ANOVA, $\mathrm{F}=31.45, \mathrm{P}<0.001)$, although no interaction effect was found between the two factors (ANOVA, P>0.05) (Fig. 3).

\section{Distribution of $\boldsymbol{C}$. raciborskii along different temperature and transparency conditions}

C. raciborskii reached high biovolume in all regions, at low and high temperatures, and in a wide range of water column transparencies as indicated by euphotic zones (Tab. 2). C. raciborskii dominance of BV (i.e., $>40 \%$ of $\mathrm{BV}$ ) was found, in general, at $\mathrm{z}_{\mathrm{eu}}>1 \mathrm{~m}$ and up to $5 \mathrm{~m}$ (Fig. 4), and of $>80 \%$ of BV was reached at temperatures between 8 and $30^{\circ} \mathrm{C}$. The lowest maximum biovolume of the species $(>18.5 \%$ of $\mathrm{BV})$ was registered in two temperate lakes (Bnińskie and Bytyńskie) (Tab. 2). However, in another temperate lake (Alte Donau), C. raciborskii dominated the phytoplankton community $(72.3 \%$ of BV) at low temperature $\left(1.97^{\circ} \mathrm{C}\right)$ (Fig. 5). In the subtropical lake (Javier), the phytoplankton was dominated by $C$. raciborskii at low and high temperatures $\left(15^{\circ} \mathrm{C}: 18 \mathrm{~mm}^{3}\right.$ $\mathrm{L}^{-1}$ C. raciborskii and $79.5 \%$ C. raciborskii; $25^{\circ} \mathrm{C}: 10 \mathrm{~mm}^{3}$ $\mathrm{L}^{-1}$ C. raciborskii and $63.3 \%$ C. raciborskii) (Fig. 5). C. raciborskii represented a high proportion of total phytoplankton biovolume at low $\mathrm{z}_{\mathrm{eu}} / \mathrm{z}_{\text {mix }}$ ratio with temperatures below $25^{\circ} \mathrm{C}$ and at high $\mathrm{z}_{\mathrm{eu}} / \mathrm{z}_{\text {mix }}$ ratio at higher temperatures (Fig. 6). No significant differences were found between regions $(\mathrm{K}-\mathrm{W}, \mathrm{P}>0.05)$ in $\%$. raciborskii, but significant differences were found between lakes $(\mathrm{K}-\mathrm{W}$, $\mathrm{P}<0.05$ ) and most of the lakes' pairwise combinations

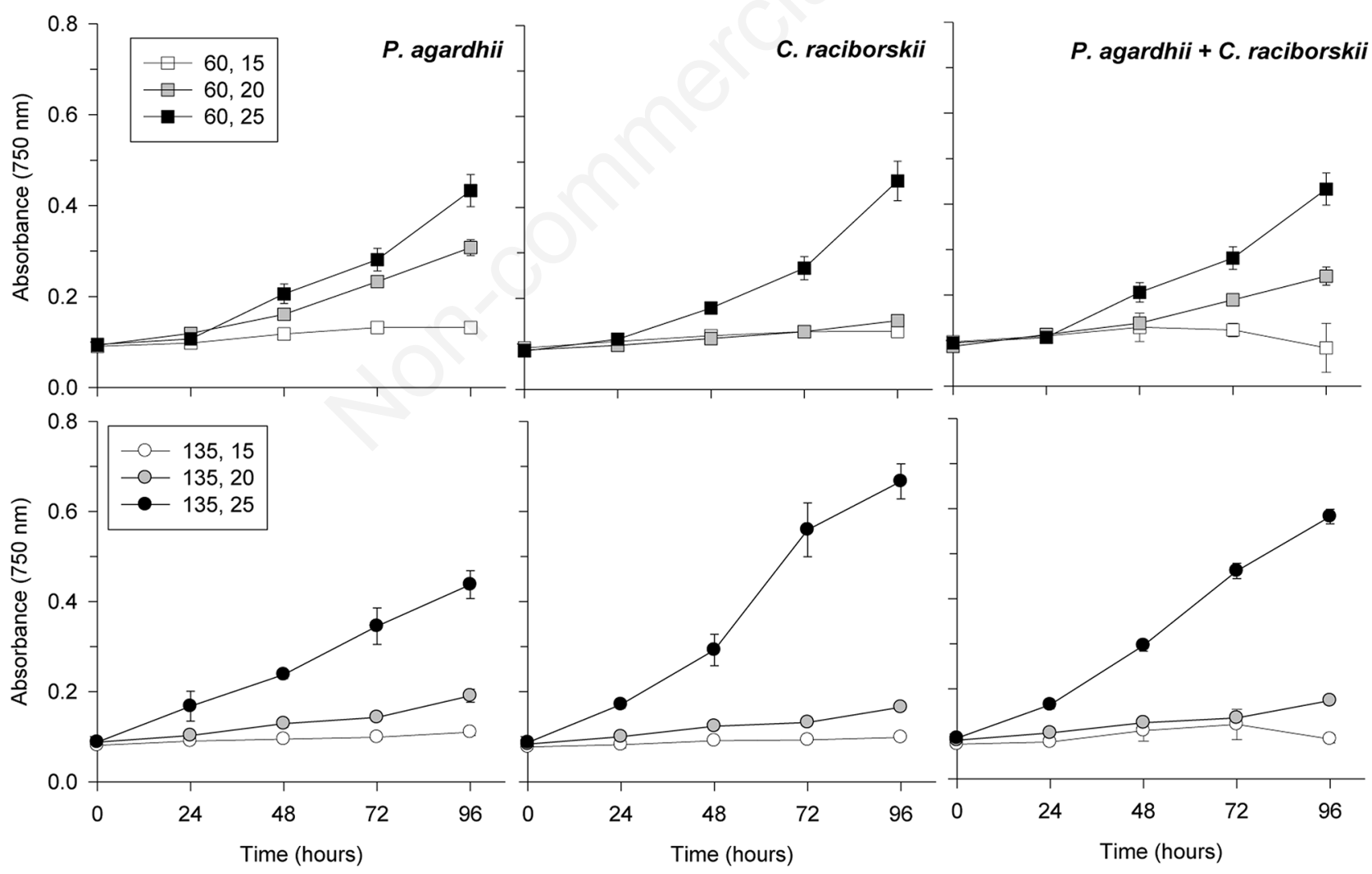

Fig. 1. Growth curves of Cylindrospermopsis raciborskii (C. raciborskii) and Planktothrix agardhii (P. agardhii) monocultures and mixed cultures (C. raciborskii and P. agardhii) at three temperatures $\left(15^{\circ} \mathrm{C}\right.$ : white, $20^{\circ} \mathrm{C}$ : grey and $25^{\circ} \mathrm{C}$ : black $)$ and two light intensities: low (upper panels; $60 \mu \mathrm{mol}$ photon $\mathrm{m}^{-2} \mathrm{~s}^{-1}$ : squares) and high (lower panels; $135 \mu \mathrm{mol}$ photon $\mathrm{m}^{-2} \mathrm{~s}^{-1}$ : circles). Data are averages with standard deviations (vertical lines), $\mathrm{n}=3$. 
(Dunn's Method, $\mathrm{P}<0.05$, except for Alte Donau vs Funil, Javier vs Juturnaíba, Funil vs Cruzeta and Juturnaiba vs Bnińskie, where $\mathrm{P}>0.05$ ).

The coefficient of variation $(\mathrm{CV})$ of $\%$ C. raciborskii was positively correlated with lake area (Spearman, $\mathrm{P}=0.727$, $\mathrm{P}<0.05$ ) and with its maximum biovolume per lake (Spearman, $\mathrm{P}=0.738, \mathrm{P}<0.05) . \%$. raciborskii was also positively
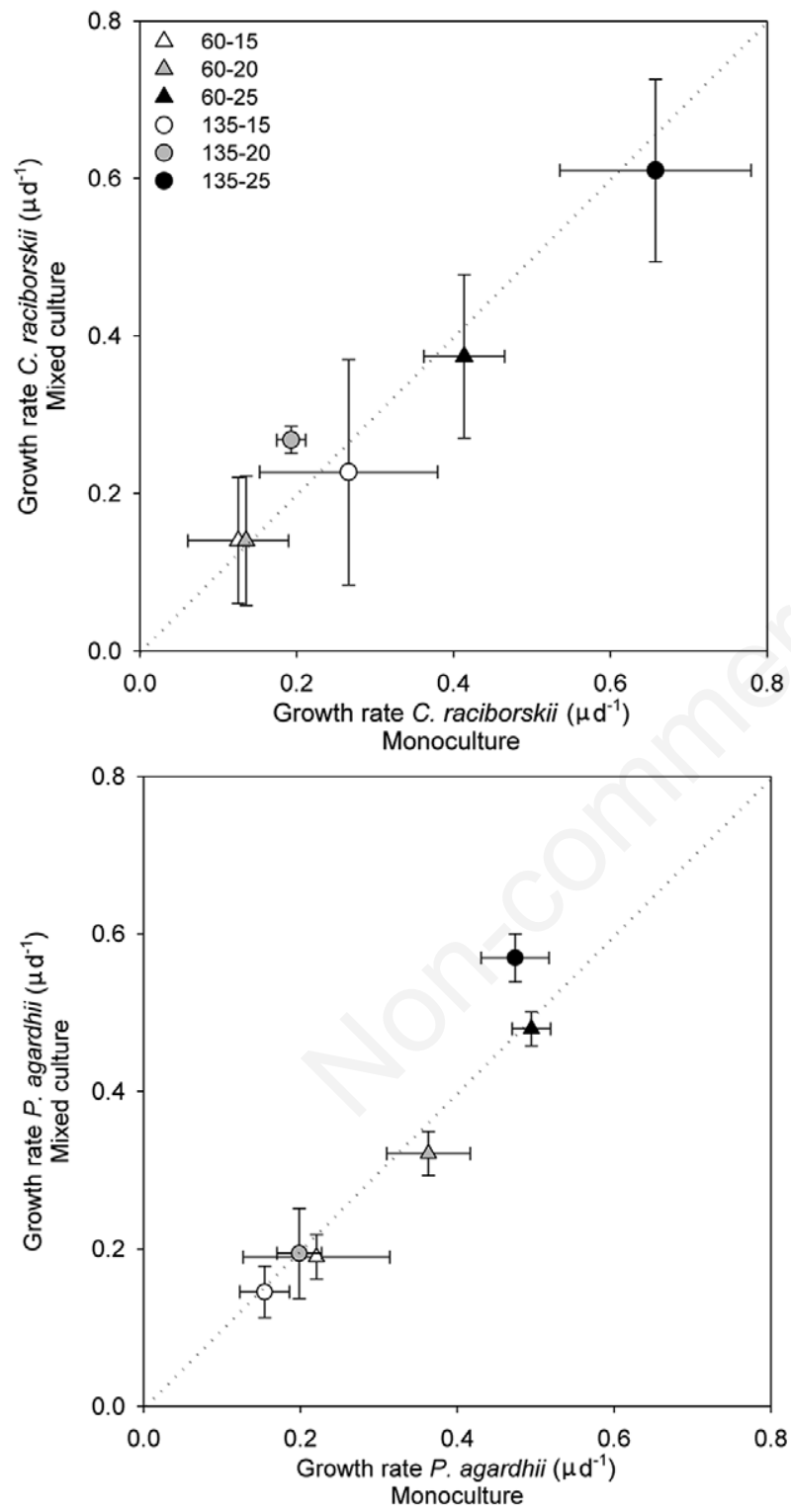

Fig. 2. Growth rates of C. raciborskii in monocultures and mixed cultures with $P$. agardhii (upper panel) and $P$. agardhii in monocultures and mixed cultures with $C$. raciborskii (lower panel) under 60 or $135 \mu \mathrm{mol}$ photons $\mathrm{m}^{-2} \mathrm{~s}^{-1}$ (triangles and circles, respectively) and at 15,20 and $25^{\circ} \mathrm{C}$ (white, grey and black, respectively). The solid diagonal line indicates a theoretically perfect correlation 1:1. Data are average with standard deviation, $n=3$. correlated with $\mathrm{z}_{\mathrm{eu}}$ and $\mathrm{z}_{\mathrm{eu}} / \mathrm{z}_{\text {mix }}$ ratio (Spearman, $\mathrm{P}=0.359$, $\mathrm{P}<0.05$ and $\mathrm{P}=0.281, \mathrm{P}<0.05$, respectively), while no correlation was found with temperature $(\mathrm{P}>0.05)$ (Figs. 5 and $6)$. The presence of $C$. raciborskii when it represented $>10 \%$ of BV and when it was dominant $(>40 \%$ of BV) responded negatively to latitude and temperature and positively with light (Tab. 3). When $C$. raciborskii was

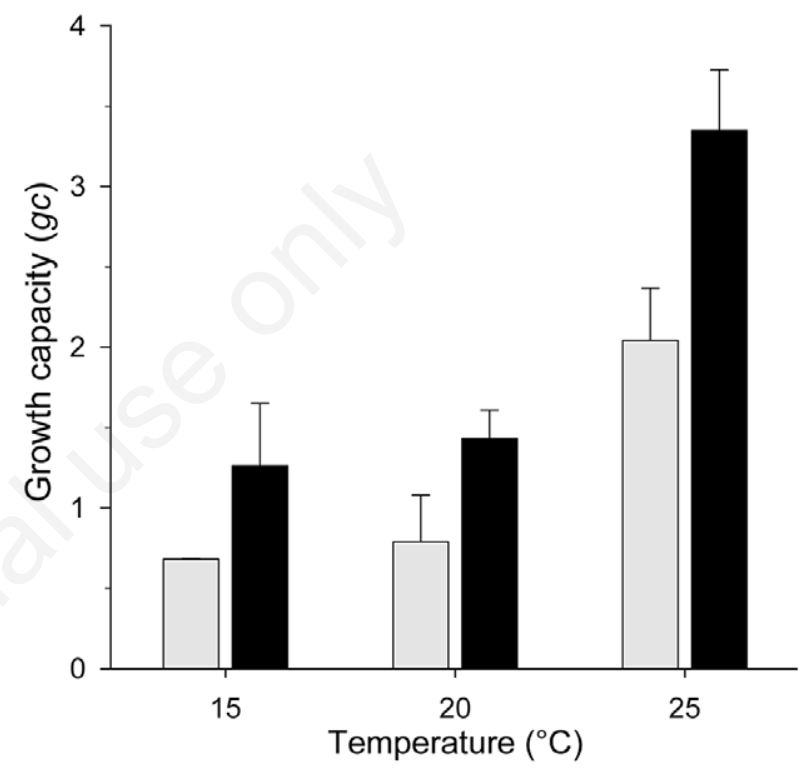

Fig. 3. Growth capacity index for $C$. raciborskii at two light intensities ( 60 and $135 \mu \mathrm{mol}$ photons $\mathrm{m}^{-2} \mathrm{~s}^{-1}$ ) and three temperatures in mix cultures with $P$. agardhii. Data are averages with standard deviations (vertical lines, grey and black bars, respectively), $n=3$.

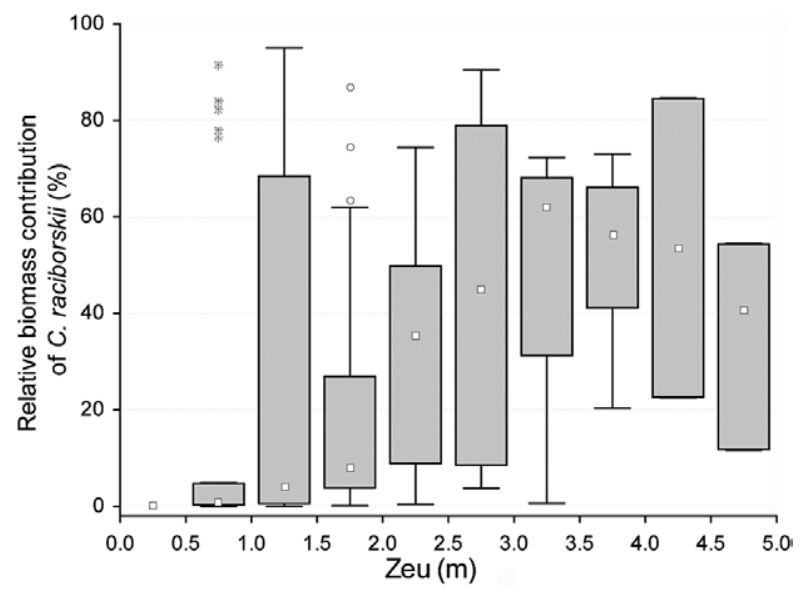

Fig. 4. Contribution of Cylindrospermopsis raciborskii to total biovolume in relation to the depth of the euphotic zone for all data and all lakes. Median (white), percentiles 25\% and $75 \%$ (grey), range (vertical lines), outliers $\left(^{\circ}\right)$ and extremes $(*)$ are shown. 
dominant ( $>40 \%$ of BV) there was no significant interaction between factors; when sites where $C$. raciborskii $>10 \%$ of $\mathrm{BV}$, a combined effect of temperature and latitude was found (Tab. 3).

\section{DISCUSSION}

Temperature has been one of the main factors invoked to explain changes in the biogeographic distribution and abundance of Cylindrospermopsis raciborskii. In our study we examined temperature, both alone and in combination with light, in an effort to better understand their implications for the expansion of C. raciborskii. Our field and experimental approaches provide new data which support the hypothesis that this species is able to grow and dominate the phytoplankton community in a wide range of temperatures, as stated in other studies, and is also significantly promoted by elevated light intensities. This last aspect is critical, since transparent waters, usually at lower trophic levels, may thus also prove to be appropriate habitats for the initial growth and later dominance of this harmful cyanobacterium. Light intensity and water transparency are factors that are often overlooked in water management. Our results suggest that transparent freshwaters from temperate to tropical regions may be suitable environments for the potential increase in population abundance of $C$. raciborskii.

It is usually assumed that cyanobacteria are superior competitors at high temperature relative to other phytoplankton species (Paerl and Huisman, 2008; Paerl and Otten, 2013). However, recent experimental studies found no differences in the growth rates of eight
Cyanobacteria (including C. raciborskii) and eight Chlorophyta species incubated at higher $\left(35^{\circ} \mathrm{C}\right)$ and lower $\left(25^{\circ} \mathrm{C}\right)$ temperatures (Lürling et al., 2013). Other studies demonstrated growth at low temperature $\left(15^{\circ} \mathrm{C}\right)$ in experiments (Chonudomkul et al., 2004) or maximum growth rates at $24^{\circ} \mathrm{C}$, and not at $30^{\circ} \mathrm{C}$ as generally reported (Saker and Griffiths, 2000).

In our study, C. raciborskii dominated the phytoplankton at high and low temperatures $\left(\right.$ e.g., $1.96^{\circ} \mathrm{C}$, Alte Donau) and was capable of phytoplankton dominance at different temperatures (Fig. 4), in agreement with other studies (Stüken et al., 2006; Moreira et al., 2015; Dokulil, 2015). Vegetative cells of C. raciborskii can survive at low temperatures $\left(<12^{\circ} \mathrm{C}\right)$ and low light intensities, as found in Alte Donau Lake (Dokulil, 2015). C. raciborskii populations appeared in German lakes when temperature increased above 15 to $17^{\circ} \mathrm{C}$ (Wiedner et al., 2007), and were negatively correlated with temperature in a survey that analyzed 46 Polish lakes (Kokociński and Soininen, 2012). The experimental and field data, taken together, thus support recent findings that indicate that the species can grow in a wide range of temperatures (Bonilla et al., 2012; Dokulil, 2015). The factors that affect the distribution of $C$. raciborskii are therefore more likely derivative effects of temperature, such as mixing regime changes, instead of temperature itself.

In our dataset, $C$. raciborskii dominated the phytoplankton ( $>40 \%$ of BV) across a wide range of biovolume, with no differences between tropical lakes and those of other latitudes in terms of $C$. raciborskii biomass or its dominance of the phytoplankton. The total

Tab. 1. Results of the three ways ANOVA for differences in growth rate of each species (C. raciborskii and P. agardhii) under different treatments (light and temperature) and culture conditions (mono- and mixed cultures).

\begin{tabular}{|c|c|c|c|c|c|}
\hline & Df & SS & MS & F-statistic & $\mathbf{P}$ \\
\hline \multicolumn{6}{|l|}{ C. raciborskii } \\
\hline Intercept & 1 & 1.0044 & 1.0044 & 3693 & $0.0003 * *$ \\
\hline Mono-mixed & 1 & 0.0010 & 0.0010 & 3.802 & 0.1905 \\
\hline Light & 1 & 0.0602 & 0.0602 & 221.4 & $0.0045 * *$ \\
\hline Temperature & 2 & 0.2682 & 0.1341 & 493.1 & $0.0020 * *$ \\
\hline Mono-mixed-light & 1 & 0.0001 & 0.0001 & 0.363 & 0.6083 \\
\hline Mono-mixed-temp & 2 & 0.0064 & 0.0032 & 11.71 & 0.0787 \\
\hline Light-temp & 2 & 0.0141 & 0.0071 & 25.96 & $0.0371^{*}$ \\
\hline Error & 2 & 0.0005 & 0.0003 & & \\
\hline \multicolumn{6}{|l|}{ P. agardhii } \\
\hline Intercept & 1 & 1.2056 & 1.2056 & 2138 & $0.0005^{* *}$ \\
\hline Mono-mixed & 1 & $<0.0001$ & $<0.0001$ & 0.007 & 0.9411 \\
\hline Light & 1 & 0.0092 & 0.0092 & 16.38 & 0.0560 \\
\hline Temperature & 2 & 0.2273 & 0.1137 & 201.6 & $0.0050 *$ \\
\hline Mono-mixed-light & 1 & 0.0024 & 0.0024 & 4.289 & 0.1742 \\
\hline Mono-mixed-temp & 2 & 0.0025 & 0.0013 & 2.264 & 0.3064 \\
\hline Light-temp & 2 & 0.0163 & 0.0081 & 14.45 & 0.0647 \\
\hline Error & 2 & 0.0011 & 0.0006 & & \\
\hline
\end{tabular}

$D f$, degrees of freedom; SS, sum of squares; $M S$, mean sum of squares; $* P<0.05 ; * * P<0.001$. 
and relative biovolume of $C$. raciborskii in our subtropical lake (Javier Lake) was similar to those from other subtropical lakes in Brazil (Tonetta et al., 2013), China (Lei et al., 2014) and Australia (Everson et al., 2011). The three temperate lakes in the dataset (Bnińskie and Bytyńskie, Poland; Alte Donau, Austria) were all shallow, polymictic, and eutrophic to hypereutrophic (Kokociński et al., 2010), but they differed markedly in their C. raciborksii biovolumes. Similar differences were found in other studies that examined phytoplankton composition and dominance of cyanobacteria species in temperate lakes located within the same region (Briand et al., 2002; Mischke, 2003). The tropical lakes of our dataset (Funil, Juturnaíba, Tabocas and Cruzeta lakes) overlapped in their C. raciborskii biovolumes, although they differed in the relative contribution of the species to total phytoplankton biovolume, probably due to local lake characteristics and hydrodynamic constraints (De Senerpont Domis et al., 2013; Soares et al., 2013). These differences underline the importance of local conditions that favor the growth and accumulation of biomass of one particular species.
Our data show that light environment is critical for understanding the ecology and distribution of $C$. raciborskii. The species can exploit high light conditions, as found in field (Fabbro and Duivenvoorden, 1996; Dokulil and Mayer, 1996) and experimental studies (Wu et al., 2009; Mehnert et al., 2010). Our analysis showed maximum $C$. raciborskii dominance of the phytoplankton in both low $\left(\mathrm{z}_{\mathrm{eu}} / \mathrm{z}_{\text {mix }}<0.2\right)$ and high $\left(\mathrm{z}_{\mathrm{eu}} / \mathrm{z}_{\text {mix }}>1\right)$ transparency conditions, reinforcing the species' capacity for success in different light environments due to its phenotypic plasticity (Piccini et al., 2011; Mehnert et al., 2012). Furthermore, our experimental data clearly show that light intensity is a critical factor in C. raciborskii performance, as growth rates indicated a clear optimization of species fitness at high temperatures and light intensities (Fig. 2). At high light intensity $C$. raciborskii overcame the limitations imposed by low temperatures and was able to expand. However, C. raciborskii blooms are also highly tolerant of self-generated low light intensities. This was observed in low transparency conditions (i.e., $\mathrm{z}_{\mathrm{eu}} / \mathrm{z}_{\mathrm{mix}}<0.2$ ) where the species dominated the phytoplankton community (Bonilla et al., 2012). Acclimation capacity of the species to dif-

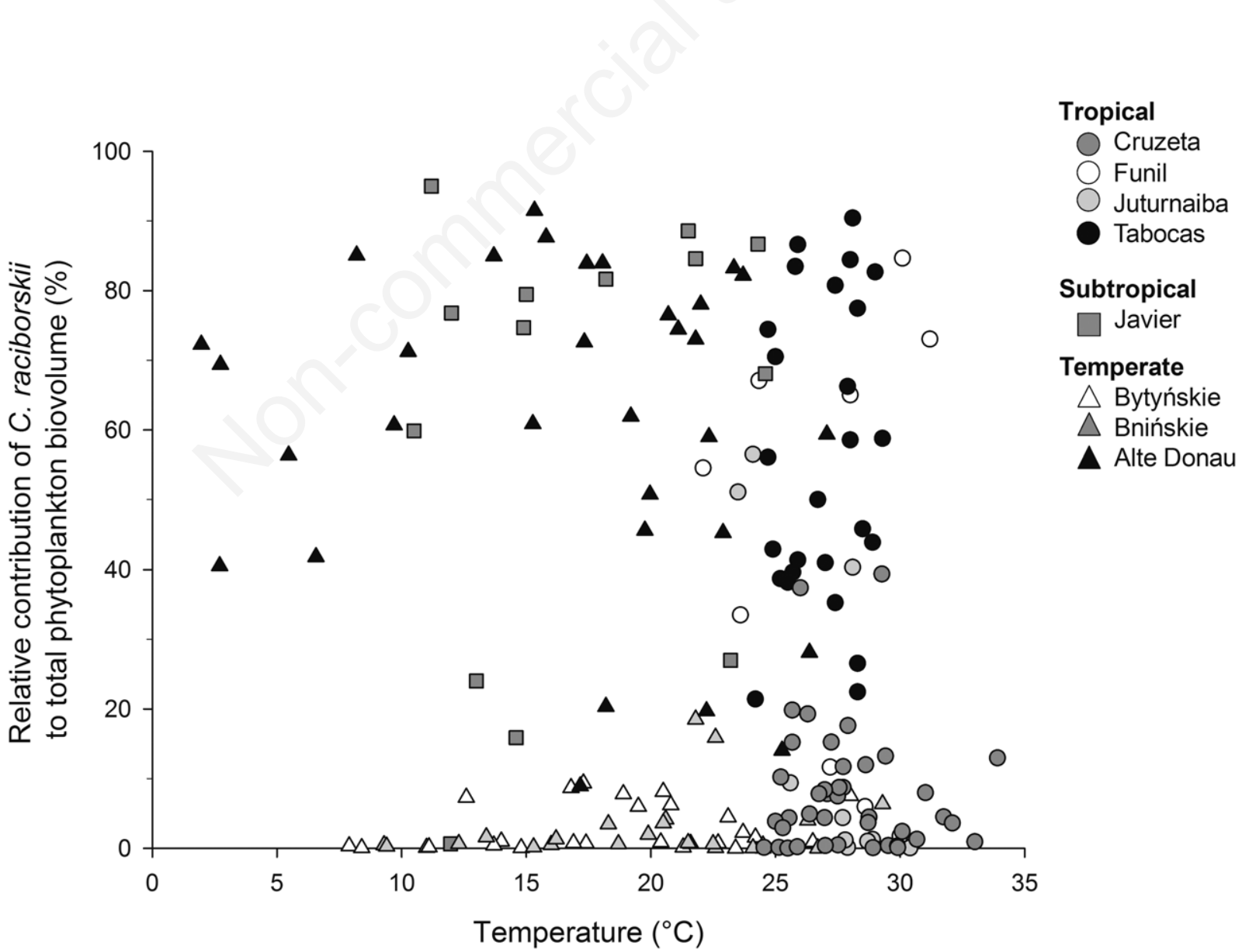

Fig. 5. Contribution of Cylindrospermopsis raciborskii, when present, to total biovolume, in relation to the water temperature for all data and the eight lakes. 


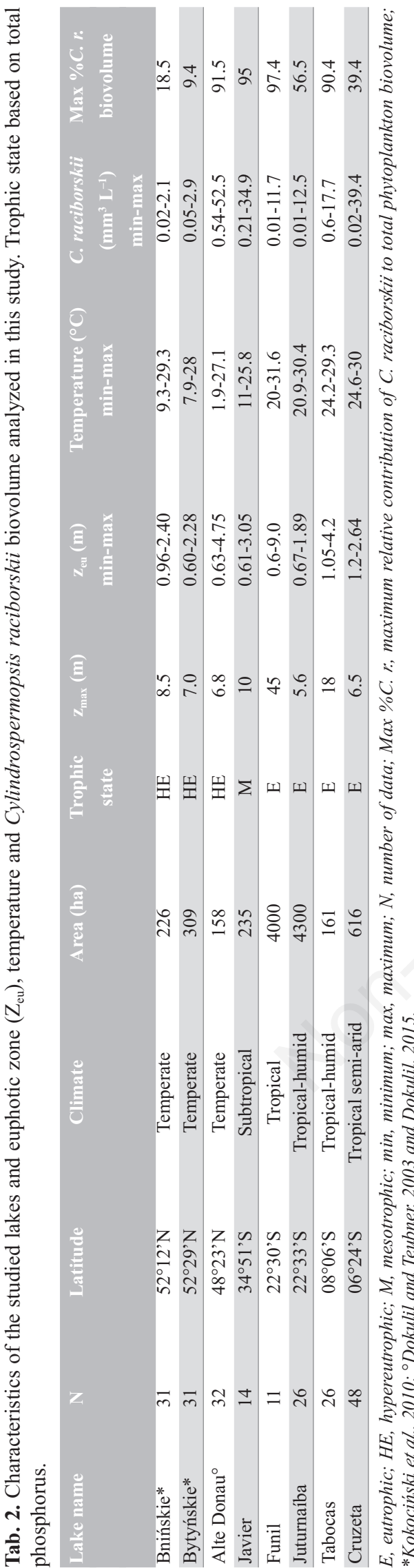

Tab. 3. Results of the final generalized linear model (GLM) analyzing the effects of location (latitude), temperature and light for the presence of $C$. raciborskii when $>10 \%$ of total biovolume $(C . r .>10 \%)\left(\mathrm{D}^{2}=37.3 \%, \mathrm{AIC}=132.7\right)$ and when C. raciborskii $>40 \%$ of total biovolume $(C . r .>40 \%)\left(\mathrm{D}^{2}=22.9 \%, \mathrm{AIC}=169.9\right)$. Results are shown for estimated coefficients, their standard errors (SE) and the statistical significance $\mathrm{P}$ for the explanatory variables.

\begin{tabular}{lcccccc} 
& \multicolumn{3}{c}{ C.r. $>10 \%$} & & \multicolumn{3}{c}{ C.r. $>40 \%$} \\
& Estimate & SE & P & Estimate & SE & P \\
Intercept & 2.3936 & 0.6498 & $0.0002^{* *}$ & -0.0477 & 0.3794 & 0.8999 \\
Temperature & -2.8537 & 0.7787 & $0.0003^{* *}$ & -1.3731 & 0.3613 & $0.0001^{* *}$ \\
\hline Latitude & -2.4242 & 0.6034 & $<0.0001^{* *}$ & -1.8605 & 0.4867 & $0.0001^{* *}$ \\
Light & 1.7157 & 0.3894 & $<0.0001^{* *}$ & 0.5712 & 0.2155 & $0.0080^{*}$ \\
\hline Interactions & & & & & & \\
$\quad$ Temp:Light & 0.6379 & 0.5066 & 0.2080 & 0.4803 & 0.2903 & 0.0980 \\
Lat:Light & 1.008 & 0.7455 & 0.1764 & 0.3351 & 0.4750 & 0.4805 \\
Temp:Lat & 2.271 & 0.7034 & $0.0012^{*}$ & 0.5405 & 0.3699 & 0.1439
\end{tabular}

Lat, latitude; Temp, temperature; Light, $Z_{e u} / Z_{m i x} * P<0.05 ; * * P<0.001$.

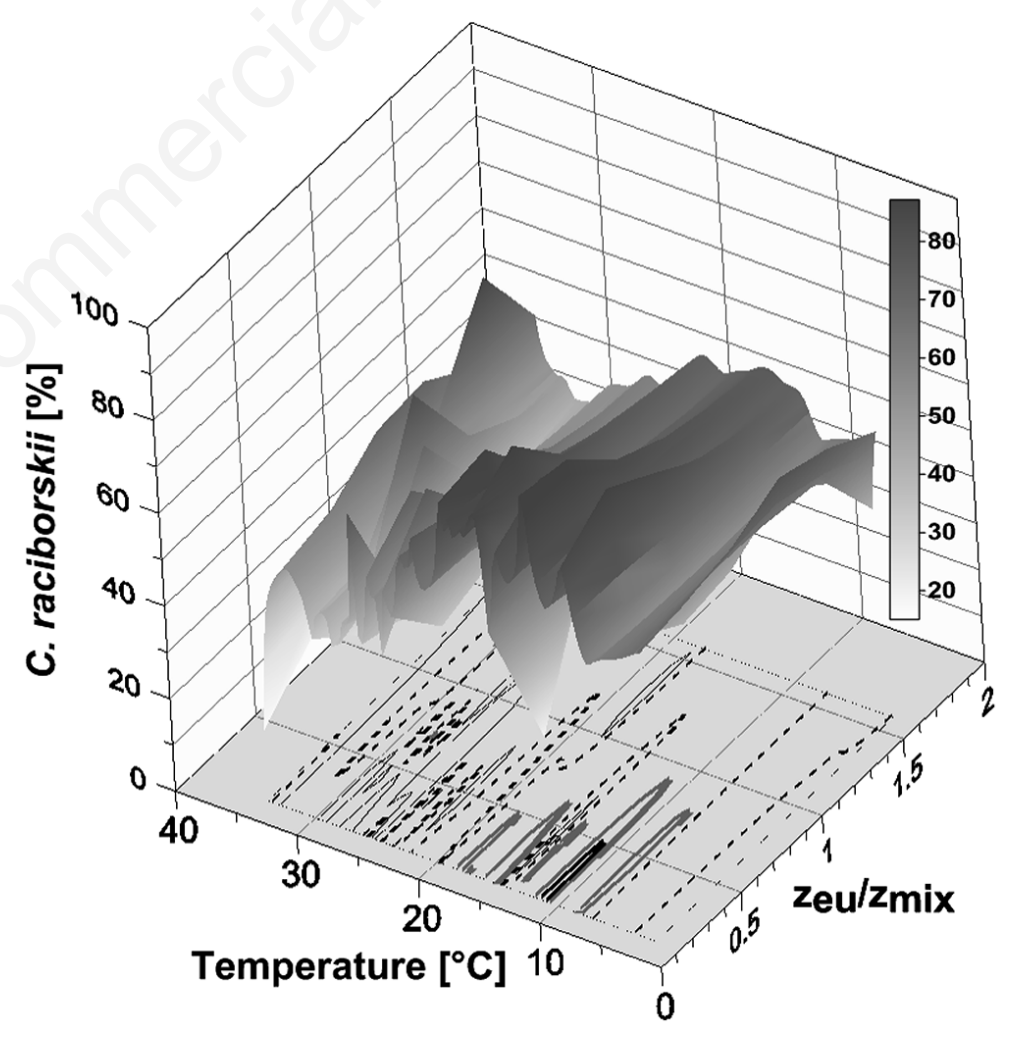

Fig. 6. Surface plot found from interpolation of the raw data (inverse distance weighting) of $\%$ C. raciborskii (grey gradient of the mesh) water temperature and euphotic zone to mixing zone ratio (zeu/zmix) of the eight studied lakes. Lines in the bottom indicates isobaths for $\%$ C. raciborskii (solid grayline, $80 \%$; solid black line, $90 \%$ ). 
ferent light conditions may explain high primary production rates in dark-acclimated populations, as shown in experiments with natural phytoplankton (O'Brien et al., 2009). Short term field experiments with $C$. raciborskii blooms showed maximum photosynthesis at high temperature $\left(28^{\circ} \mathrm{C}\right)$ with saturation at low light intensity, indicating a strong interaction between light and temperature (Kehoe et al., 2015).

\section{CONCLUSIONS}

In our study, there was no clear negative interaction between $C$. raciborskii and P. agardhii in the mixed culture short term experiments. Moreover, $P$. agardhii is a shade adapted species and its growth was favored by the presence of $C$. raciborskii at high light intensity, which might be related to the shading effect of $C$. raciborskii biomass in the mixed culture (Padisák and Reynolds, 1998; Bonilla et al., 2012). The tolerance of C. raciborskii to changes in light intensity may also help to explain its growth under a combination of environmental stresses. Light intensity and UV radiation can have consequences for $C$. raciborskii toxin expression, as shown by a recent study where greater UVB exposure enhanced C. raciborskii saxitoxin gene expression and production (Beamud et al., 2016). Also, in factorial experiments with phosphate concentrations and light intensity, Marinho et al. (2013) found that $C$. raciborskii can outcompete or be displaced by Microcystis aeruginosa, depending on the combination of the two factors and on the strains. More experimental studies including light intensity and its fluctuations are needed to identify the capacity of $\mathrm{C}$. raciborskii to overcome combinations of stress factors.

Future predicted effects of climate change include dramatic shifts in seasonal water stratification-mixing cycles that will directly affect the euphotic depth and light intensity in lakes (Karlsson et al., 2009; Posch et al., 2012). These physical changes will affect phytoplankton composition, resulting in changes in species dominance (Rühland et al., 2008; Posch et al., 2012). In this context, the importance of light as a critical factor for determining the initial growth and expansion of C. raciborskii has significant implications in the context of changing climates. The species is increasingly being found in freshwater water bodies around the world, indicating no climate restrictions (Burford et al., 2016), except for extreme polar regions. According to our data, although temperature regulates $C$. raciborskii growth in general, there is no clear temperature limitation controlling its expansion, and changing stratification dynamics in temperate lakes, due to climate change, may therefore present opportunities for the future success of this species. Water management programs must therefore take into account that even slight changes in light transparency can enhance the presence of this harmful cyanobacterium.

\section{ACKNOWLEDGEMENTS}

This work was partially financed by ANII (FCE_2007_353) and PEDECIBA Biología. We thank three anonymous reviewers for improving an earlier version of the manuscript.

\section{REFERENCES}

Amaral V, Bonilla S, Aubriot L, 2014. Growth optimization of the invasive cyanobacterium Cylindrospermopsis raciborskii in response to phosphate fluctuations. Eur. J. Phycol. 49:134-141.

Augustin N, Sauleau E-A, Wood S, 2012. On quantile quantile plots for generalized linear models. Comput. Stat. Data An. 56:2404-2409.

Beamud G, Vico P, Haakonsson S, Martínez de la Escalera G, Piccini C, Brena BM, Pirez M, Bonilla S, 2016. Influence of UV-B radiation on the fitness and toxin expression of the cyanobacterium Cylindrospermopsis raciborskii. Hydrobiologia 763:161-172.

Birks HJB, 2012. Overview of numerical methods in palaeolimnology. Tracking environmental change using lake sediments. Springer, New York.

Bittencourt-Oliveira MC, Buch B, Hereman TC, Arruda-Neto J, Moura A, Zocchi S, 2012. Effects of light intensity and temperature on Cylindrospermopsis raciborskii (Cyanobacteria) with straight and coiled trichomes: growth rate and morphology. Braz. J. Biol. 72:343-351.

Bonilla S, Aubriot L, Soares MCS, González-Piana M, Fabre A, Huszar VL, Lürling M, Antoniades D, Padisák J, Kruk C, 2012. What drives the distribution of the bloom-forming cyanobacteria Planktothrix agardhii and Cylindrospermopsis raciborskii? FEMS Microbiol. Ecol. 79: 594-607.

Briand JF, Robillot C, Quiblier-Lloberas C, Humbert J, Couté A, Bernard C, 2002. Environmental context of Cylindrospermopsis raciborskii (Cyanobacteria) blooms in a shallow pond in France. Water Res. 36:3183-3192.

Briand JF, Leboulanger C, Humbert JF, Bernard C, Dufour P, 2004. Cylindrospermopsis raciborskii (Cyanobacteria) invasion at mid-latitudes: selection, wide physiological tolerance or global warming? J. Phycol. 40:231-238.

Burford MA, Beardall J, Willis A, Orr PY, Magalhaes VF, Rangel LM, Azevedo SMFOE, Neilan BA, 2016. Understanding the winning strategies used by the bloom-forming cyanobacterium Cylindrospermopsis raciborskii. Harmful Algae 54:44-53.

Chonudomkul D, Yongmanitchai W, Theeragool G, Kawachi M, Kasai F, Kaya K, Watanabe MM, 2004. Morphology, genetic diversity, temperature tolerance and toxicity of Cylindrospermopsis raciborskii (Nostocales, Cyanobacteria) strains from Thailand and Japan. FEMS Microbiol. Ecol. 48:345-355.

De Senerpont Domis LN, Elser JJ, Gsell AS, Huszar VL, Ibelings BW, Jeppesen E, Kosten S, Mooij WM, Roland F, Sommer U, 2013. Plankton dynamics under different climatic conditions in space and time. Freshwater Biol. 58: 463-482.

Dokulil M, 2015. Vegetative survival of Cylindrospermopsis 
raciborskii (Cyanobacteria) at low temperature and low light. Hydrobiologia 764:241-247.

Dokulil MT, Mayer J, 1996. Population dynamics and photosynthetic rates of a Cylindrospermopsis-Limnothrix association in a highly eutrophic urban lake, Alte Donau, Vienna, Austria. Arch. Hydrobiol. 117:179-195.

Dokulil MT, Teubner K, 2000. Cyanobacterial dominance in lakes. Hydrobiologia 438:1-12.

Doney SC, 2006. Oceanography: plankton in a warmer world. Nature 444:695-696.

Everson S, Fabbro L, Kinnear S, Wright P, 2011. Extreme differences in akinete, heterocyte and cylindrospermopsin concentrations with depth in a successive bloom involving Aphanizomenon ovalisporum (Forti) and Cylindrospermopsis raciborskii (Woloszynska) Seenaya and Subba Raju. Harmful Algae 10:265-276.

Fabbro LD, Duivenvoorden L, 1996. Profile of a bloom of the cyanobacterium Cylindrospermopsis raciborskii (Woloszynska) Seenaya and Subba Raju in the Fitzroy River in tropical central Queensland. Mar. Freshwater Res. 47:685-694.

Gomes A, Marinho M, Azevedo S, Ferrão-Filho A, 2013. Which factors are related to the success of Cylindrospermopsis raciborskii in Brazilian aquatic systems, p. 73-94. In: A.S. Ferrão-Filho (ed.) Cyanobacteria: ecology, toxicology and management. Nova Science Publishers, Inc., Hauppauge.

Guisan A, Zimmermann NE, 2000. Predictive habitat distribution models in ecology. Ecol. Modell. 135:147-186.

Hillebrand H, Dürselen CD, Kirschtel D, Pollingher U, Zohary $\mathrm{T}, 1999$. Biovolume calculation for pelagic and benthic microalgae. J. Phycol. 35:403-424.

Isvánovics V, Shafik HM, Présing M, Juhos S, 2000. Growth and phosphate uptake kinetics of the cyanobacterium, Cylindrospermopsis raciborskii (Cyanophyceae) in throughflow cultures. Freshwater Biol. 43:257-275.

Jensen P, Jeppesen E, Olrik K, Kristensen P, 1994. Impact of nutrients and physical factors on the shift from cyanobacterial to chlorophyte dominance in shallow Danish lakes. Can. J. Fish Aquat. Sci. 51:1692-1699.

Karlsson J, Byström P, Ask J, Ask P, Persson L, Jansson M, 2009. Light limitation of nutrient-poor lake ecosystems. Nature 460:506-509.

Kehoe M, O’Brien K, Grinham A, Burford M, 2015. Primary production of lake phytoplankton, dominated by the cyanobacterium Cylindrospermopsis raciborskii, in response to irradiance and temperature. Inland Waters 5:93-100.

Kenesi G, Shafik HM, Kovács AW, Herodek S, Présing M, 2009. Effect of nitrogen forms on growth, cell composition and $\mathrm{N}_{2}$ fixation of Cylindrospermopsis raciborskii in phosphorus-limited chemostat cultures. Hydrobiologia 623:191-202.

Kirk JTO, 1994. Light and photosynthesis in aquatic ecosystems, 2nd ed. Cambridge University Press, Cambridge.

Kokociński M, Stefaniak K, Mankiewicz-Boczek J, Izydorczyk K, Soininen J, 2010. The ecology of the invasive cyanobacterium Cylindrospermopsis raciborskii (Nostocales, Cyanophyta) in two hypereutrophic lakes dominated by Planktothrix agardhii (Oscillatoriales, Cyanophyta). Eur. J. Phycol. 45:365-374.

Kokociński M, Soininen J, 2012. Environmental factors related to the occurrence of Cylindrospermopsis raciborskii
(Nostocales, Cyanophyta) at the north-eastern limit of its geographical range. Eur. J. Phycol. 47:12-21.

Komárek J, Komárková J, 2003. Phenotype diversity of the cyanoprokaryotic genus Cylindrospermopsis (Nostocales); review 2002. Czech Phycol. 3:1-30.

Lei L, Peng L, Huang X, Han B-P, 2014. Occurrence and dominance of Cylindrospermopsis raciborskii and dissolved cylindrospermopsin in urban reservoirs used for drinking water supply, South China. Environ. Monit. Assess. 186:3079-3090.

Litchman E, 2010. Invisible invaders: non-pathogenic invasive microbes in aquatic and terrestrial ecosystems. Ecol. Lett. 13:1560-1572.

Lürling M, Eshetu F, Faassen EJ, Kosten S, Huszar VL, 2013. Comparison of cyanobacterial and green algal growth rates at different temperatures. Freshwater Biol. 58:552-559.

Marinho MM, Huszar VL, 2002. Nutrient availability and physical conditions as controlling factors of phytoplankton composition and biomass in a tropical reservoir (Southeastern Brazil). Arch. Hydrobiol. 153:443-468.

Marinho MM, Souza MBG, Lürling M, 2013. Light and phosphate competition between Cylindrospermopsis raciborskii and Microcystis aeruginosa is strain dependent. Microb. Ecol. 66:479-488.

Mehnert G, Leunert F, Cirés S, Jöhnk KD, Rücker J, Nixdorf B, Wiedner C, 2010. Competitiveness of invasive and native cyanobacteria from temperate freshwaters under various light and temperature conditions. J. Plankton Res. 32:1009-1021.

Mehnert G, Rücker J, Nicklisch A, Leunert F, Wiedner C, 2012. Effects of thermal acclimation and photoacclimation on lipophilic pigments in an invasive and a native cyanobacterium of temperate regions. Eur. J. Phycol. 47:182-192.

Mischke U, 2003. Cyanobacteria associations in shallow polytrophic lakes: influence of environmental factors. Acta Oecol. 24:S11-S23.

Moreira C, Fathalli A, Vasconcelos V, Antunes A, 2015. Phylogeny and biogeography of the invasive cyanobacterium Cylindrospermopsis raciborskii. Arch. Microbiol. 197:47-52.

O'Brien KR, Burford MA, Brookes JD, 2009. Effects of light history on primary productivity in a phytoplankton community dominated by the toxic cyanobacterium Cylindrospermopsis raciborskii. Freshwater Biol. 54: 272-282.

Padisák J, 1997. Cylindrospermopsis raciborskii (Woloszynska) Seenayya et Subba Raju, an expanding, highly adaptive cyanobacterium: worldwide distribution and review of its ecology. Arch Hydrobiol 107:563-593.

Padisák J, Reynolds CS, 1998. Selection of phytoplankton associations in Lake Balaton, Hungary, in response to eutrophication and restoration measures, with special reference to the cyanoprokaryotes. Hydrobiologia 384:41-53.

Paerl HW, Huisman J, 2008. Blooms like it hot. Science 320:57.

Paerl HW, Otten TG, 2013. Harmful cyanobacterial blooms: causes, consequences, and controls. Microb. Ecol. 65: 995-1010.

Paerl HW, Paul VJ, 2012. Climate change: links to global expansion of harmful cyanobacteria. Water Res. 46:349-1363.

Piccini C, Aubriot L, Fabre A, Amaral V, González-Piana M, Giani A, Figueredo CC, Vidal L, Kruk C, Bonilla S, 2011. Genetic and eco-physiological differences of South American Cylindrospermopsis raciborskii isolates support the hypothesis of multiple ecotypes. Harmful Algae 10:644-653. 
Pierangelini M, Stojkovic S, Orr PT, Beardall J, 2014. Photosynthetic characteristics of two Cylindrospermopsis raciborskii strains differing in their toxicity. J. Phycol. 50:292-302.

Posch T, Köster O, Salcher MM, Pernthaler J, 2012. Harmful filamentous cyanobacteria favoured by reduced water turnover with lake warming. Nature Clim. Change 2:809-813.

Reynolds CS, 2006. The ecology of phytoplankton. Cambridge University Press, Cambridge.

Rücker J, Tingwey EI, Wiedner C, Anu CM, Nixdorf B, 2009. Impact of the inoculum size on the population of Nostocales cyanobacteria in a temperate lake. J. Plankton Res. 31: 1151-1159.

Rühland K, Paterson AM, Smol JP, 2008. Hemispheric-scale patterns of climate-related shifts in planktonic diatoms from North American and European lakes. Glob. Change Biol. 14:2740-2754.

Saker ML, Eaglesham GK, 1999. The accumulation of cylindrospermopsin from the cyanobacterium Cylindrospermopsis raciborskii in tissues of the Redclaw crayfish Cherax quadricarinatus. Toxicon 37:1065-1077.

Saker ML, Griffiths DJ, 2000. The effect of temperature on growth and cylindrospermopsin content of seven isolates of Cylindrospermopsis raciborskii (Nostocales, Cyanophyceae) from water bodies in northern Australia. Phycologia 39:349354.

Scheffer M, Rinaldi S, Gragnani A, Mur LR, van Nes EH, 1997. On the dominance of filamentous cyanobacteria in shallow, turbid lakes. Ecology 78:272-282.

Sinha R, Pearson LA, Davis TW, Burford MA, Orr PT, Neilan BA, 2012. Increased incidence of Cylindrospermopsis raciborskii in temperate zones-is climate change responsible? Water Res. 46:1408-1419.

Soares MCS, de A Rocha M, Marinho MM, Azevedo S, Branco CW, Huszar VL, 2009. Changes in species composition during annual cyanobacterial dominance in a tropical reservoir: physical factors, nutrients and grazing effects. Aquat. Microb. Ecol. 57:137-149.

Soares MCS, Huszar VL, Miranda MN, Mello MM, Roland F, Lürling M, 2013. Cyanobacterial dominance in Brazil: distribution and environmental preferences. Hydrobiologia $717: 1-12$

Wofsy CS, 1983. A simple model to predict extintion coefficients and phytoplankton biomass in eutrophic waters. Limnol. Oceanogr. 28:1144-1155.

Sperfeld E, Schmidtke A, Gaedke U, Weithoff G, 2010. Productivity, herbivory, and species traits rather than diversity influence invasibility of experimental phytoplankton communities. Oecologia 163:997-1010.

Stüken A, Rücker J, Endrulat T, Preussel K, Hemm M, Nixdorf B, Karsten U, Wiedner C, 2006. Distribution of three alien cyanobacterial species (Nostocales) in northeast Germany: Cylindrospermopsis raciborskii, Anabaena bergii and Aphanizomenon aphanizomenoides. Phycologia 45:696-703.

Sukenik A, Hadas O, Kaplan A, Quesada A, 2012. Invasion of Nostocales (cyanobacteria) to subtropical and temperate freshwater lakes - physiological, regional, and global driving forces. Front. Microbiol. 3:86-95.

Tonetta D, Petrucio MM, Laudares-Silva R, 2013. Temporal variation in phytoplankton community in a freshwater coastal lake of southern Brazil. Acta Limnol. Bras. 25:99-110.

Utermöhl H, 1958. Toward the improvement of the quantitative phytoplankton method (in German). Mitt. Int. Ver. Theor. Angew. Limnol. 9:1-38.

Wiedner C, Rücker J, Brüggemann R, Nixdorf B, 2007. Climate change affects timing and size of populations of an invasive cyanobacterium in temperate regions. Oecologia 152:473-484.

Wu Z, Shi J, Li R, 2009. Comparative studies on photosynthesis and phosphate metabolism of Cylindrospermopsis raciborskii with Microcystis aeruginosa and Aphanizomenon flos-aquae. Harmful Algae 8:910-915. 